\title{
REVIEW
}

\section{Olfactory Sensitivity in Mammalian Species}

\author{
M. WACKERMANNOVÁ ${ }^{1}$, L. PINC ${ }^{2},{ }^{\dagger}$ L. JEBAVÝ ${ }^{3}$ \\ ${ }^{1}$ Department of Zoology and Fisheries, Faculty of Agrobiology, Food and Natural Resources, Czech \\ University of Life Sciences Prague, Czech Republic, ${ }^{2}$ Canine Behavior Research Center, \\ Department of Animal Science and Ethology, Faculty of Agrobiology, Food and Natural Resources, \\ Czech University of Life Sciences Prague, Czech Republic, ${ }^{3}$ Department of Animal Science and \\ Ethology, Faculty of Agrobiology, Food and Natural Resources, Czech University of Life Sciences \\ Prague, Czech Republic
}

Received November 13, 2014

Accepted February 5, 2016

On-line April 12, 2016

\begin{abstract}
Summary
Olfaction enables most mammalian species to detect and discriminate vast numbers of chemical structures called odorants and pheromones. The perception of such chemical compounds is mediated via two major olfactory systems, the main olfactory system and the vomeronasal system, as well as minor systems, such as the septal organ and the Grueneberg ganglion. Distinct differences exist not only among species but also among individuals in terms of their olfactory sensitivity; however, little is known about the mechanisms that determine these differences. In research on the olfactory sensitivity of mammals, scientists thus depend in most cases on behavioral testing. In this article, we reviewed scientific studies performed on various mammalian species using different methodologies and target chemical substances. Human and non-human primates as well as rodents and dogs are the most frequently studied species. Olfactory threshold studies on other species do not exist with the exception of domestic pigs. Olfactory testing performed on seals, elephants, and bats focused more on discriminative abilities than on sensitivity. An overview of olfactory sensitivity studies as well as olfactory detection ability in most studied mammalian species is presented here, focusing on comparable olfactory detection thresholds. The basics of olfactory perception and olfactory sensitivity factors are also described.
\end{abstract}

\section{Key words}

Olfaction • Sensitivity • Odor detection threshold • Mammals

\section{Corresponding author}

M. Wackermannová, Department of Zoology and Fisheries, Faculty of Agrobiology, Food and Natural Resources, Czech University of Life Sciences Prague, Kamycka 129, 16000 Prague 6, Czech Republic. E-mail: wackermannova@gmail.com

\section{Introduction}

Chemosensory systems develop very early in ontogeny and are found in almost every animal. The mammalian sense of smell detects and discriminates between innumerable substances that have very diverse chemical structures and features (Corcelli et al. 2010). The omnipresent chemical stimuli enable detection and discrimination of home range, conspecifics, mates, mother, food resources, predators, and prey. Chemosensation is critical for survival and reproductive success (Wilson 2006). Many species use chemical cues to recognize genetically related kin, even the identity of conspecifics using individual olfactory cues in order to avoid inbreeding as well as to determine the animal's reproductive status (Wilson 2006, Cometto-Muniz and Abraham 2008). Olfaction also helps protects the entire organism as this system provides an early warning system for the detection of health hazards and imminent threats (fire, leaking natural gas, rotten food, or toxins) and plays a critical role in nutrition (Laska and Hudson 1993, Hawkes and Doty 2009). The sensory and hedonic 
evaluations of most food-related flavors are mainly dependent on olfactory perception (Nevitt 2000).

Chemosensory-based communication is a vital signaling tool (Frasnelli et al. 2011). From the most gregarious to the most solitary, all animals need to coordinate their activities with others of the same species. This coordination is based on communication (Laberge and Hara 2004), which involves utilization of chemical signals known as pheromones (sexual attractant pheromones, mammary pheromones, aggression pheromones, alarm pheromones, marking pheromones) (Brennan 2010).

Olfactory sensitivity in mammals has been studied since the 1960s, but experiments focused on an exact olfactory threshold are rare. The small number of these experiments differs in methods as well as in results. The main aim of this review is to present the olfactory thresholds of mammalian species and to show the exclusivity of the olfactory system in mammals, despite the differences in the results of individual studies.

There has been a long-term effort to compare odor perception in humans and animals. The comparison may develop scientific evidence concerning hypotheses about relative olfactory powers in humans and other mammalian species. An important criterion is the integration of human psychophysical results with animal results in similar studies, as animal results may approximate the neural mechanism and olfactory perception in humans (Walker and Jennings 1991).

\section{What is olfaction?}

Olfaction mediates the perception of volatile chemicals, which convey information about the environment to the receiver. Variations in the precise structure of individual odorant molecules, concentrations of those molecules, and specific combinations and relative concentrations of components in a mixture of odorant molecules provide crucial information about the surrounding world. Given that most odors are complex mixtures of a number of single components, the discrimination of one odor from another is difficult, and previous experience enhances odor discrimination in mammalian species (Firestein 2001, Croy et al. 2015).

Over time, a number of theories have been attempted to explain the relationship between the molecular structure and odor in the primary olfactory reception mechanism. The view of the reception mechanism evolved from the "lock and key" theories that claim molecular shape determines odor (Wright 1977, Frater 1998) over odotope theory-based identification of receptor subtypes responding not to one but to many odorants (Mori 1994, Malnic et al. 1999) to vibration theory (Turin and Yoshii 2003). This theory, based on the molecular vibrations of odorants, was first described in 1938 (Dyson 1938) and has been newly extended by Turin (2002). This theory states that odor is determined by the vibration spectrum of the molecule. The detection mechanism is based on inelastic electron tunneling, and the vibration spectra of the odorants determine their odor (Turin and Yoshii 2003), but after clean chemical deuteration studies (Block et al. 2015) the vibration theory should be reexamined (Vosshal 2015). In conclusion, no theory explaining the principles of the odorant-receptor interaction has been proved to be entirely plausible (Zarzo 2007).

Individual variations in the limits of detection for different stimuli have been known for a long time. Although individual odor thresholds vary, studies have indicated the variations within an individual are comparable to variations between individuals (Cain 1989). The olfactory threshold is the minimum concentration of a target stimulus an individual is able to reliably differentiate from a blank sample (deionized water in most studies). In recent experiments that focused on olfactory sensitivity in mammalian species, the olfactory detection threshold (ODT) was considered the limit of olfactory sensitivity.

\section{Olfactory subsystems}

In mammals, the olfactory, gustatory, and trigeminal systems are involved in chemical senses (sense of smell, taste, somatosensation). The nose, the main olfactory organ, consists of multiple olfactory subsystems, among which the main olfactory epithelium (MOE) and the vomeronasal organ (VNO) have been the most studied (Trotier 2011). The MOE is composed of two types of cells, microvillar cells and olfactory sensory neurons (OSNs), which express G-protein-coupled odorant receptors. The VNO contains two olfactory subsystems (apical and basal) and two classes of vomeronasal receptors (V1Rs and V2Rs) (Young et al. 2010). Although human embryonic VNO exerts a developmental track common to microsmatic mammals, after the initial development, the VNO regresses, with only a few vestiges persisting in adults and most 
chemoreceptor cells within the persistent vomeronasal duct (VND) wear off. By the absence of neurons and vomeronasal nerve bundles it can be deduced that the vomeronasal epithelium is not a sensory organ in adult humans (Trotier et al. 2000). The genes that code for the V1R-type and V2R-type receptor proteins are mostly nonfunctional in humans (Mohedano-Moriano et al. 2008). Although vomeronasal ducts and pits have been observed in humans (Moran et al. 1991, Stensaas et al. 1991, Boehm and Gasser 1993, Trotier and Doving 1996), evidence of functional vomeronasal receptor neurons connected to the brain has not been found in adult humans (Johnson 1998, Smith et al. 2014). In some species, there are two additional spatially segregated clusters of sensory cells, the septal organ (SO) (Storan and Key 2006) and the Grueneberg ganglion (GG), which are particularly well developed in mice (Brechbuhl et al. 2014). Each of the four physically segregated apparatuses can convey sensory information about multiple modalities and serve multiple functions. Although these chemosensory subsystems detect distinct chemical substances, the olfactory cues overlap substantially. No behavioral studies have tested the olfactory subsystems separately, since it is not possible to test only part of the complex olfactory system without an invasive intervention in the subject organism.

\section{Main factors of olfactory sensitivity}

An animal's sense of smell enables the animal to recognize and discriminate numerous airborne molecules with great accuracy and sensitivity (Wu et al. 2011). The behavioral relevance of an odorant may be an important determinant of a species' olfactory sensitivity (Laska et al. 2005a, 2007a, Olsson and Laska 2010, Ferdenzi et al. 2013). It has also been determined that olfactory acuity increases during fasting, allowing some mammalian species to detect food and environmental odors, such as those of predators, more easily (Aime et al. 2007). The connection between body weight and olfactory sensitivity has been observed in mammals, especially in rats (Thanos et al. 2013). Changes in olfactory sensitivity are related to circadian locomotor behavior as well. Odor stimuli can act as a circadian time cue that modulate circadian behavior in mammals (Abraham et al. 2013). To utilize chemical cues, animals must have olfactory systems that can deal with at least four specific issues: 1) the detection of the stimulus; 2) discrimination of the stimulus from other potentially very similar stimuli; 3 ) dealing with and, perhaps, determining relative stimulus intensity; and 4) assigning meaning to the stimulus (Wilson 2006, Wilson and Mainen 2006). Detection is the degree of presence, while recognition involves matching input, and identification is the assignment of meaning. These three different functions do not necessarily correlate with specific anatomical locations (Mombaerts 2001).

Repeated exposure is an important factor in developing olfactory sensitivity, so learning is evidently a vital part of olfactory perception (Wilson and Stevenson 2003). The synapses and receptive fields of the cerebral cortex are plastic. Modification of cortical inputs leads to synaptic changes, which are related to improved sensory perception and enhanced behavioral performance (Guthoff et al. 2009). Not only the olfactory threshold but also the olfactory discrimination of similar odorants (odor acuity) in general can improve with experience (Ferdenzi et al. 2013), and the ability to successfully distinguish between similar odorants depends on the specific behavioral response of particular species (Giannaris et al. 2002, Wiltrout et al. 2003). The role of experience was found even in the prenatal stage in the rabbit (Coureaud et al. 2004). Some studies suggested that repeated exposure to an odorant may influence the threshold level. The exposure to either amyl acetate or androstenone in mice leads to enhanced sensitivity (Yee and Wysocki 2001). Conversely, some investigations found that repeated or prolonged exposure to an odorant decreases olfactory sensitivity to that odorant; however, the sensitivity recovers over time in the absence of exposure (Hudson 1999). It seems to be dependent on the concentration of the odor as well as on the duration of exposure (Moberg et al. 1999). The detection threshold obtained before and after exposure also shows an adaptation effect that is characteristic of continuous exposure (Haehner et al. 2007, Hummel et al. 2007). The adaptation and desensitization of the olfactory response were thoroughly reviewed by Kleene (2008).

Some odorants smell qualitatively different at high concentrations. Higher concentrations of any odorant are likely to result in progressively more widespread binding to different types of receptors (Duchamp-Viret et al. 1990, Malnic 1999). Rabbit pups responded to the mammary pheromone only when it was presented within a fairly limited concentration range. Only a specific concentration leads to the behavioral response. This is consistent with the notion that higher concentrations actively recruit more receptors, thus 
changing the quality of the receptor output (Coureaud et al. 2004). It has also been suggested that some olfactory sensitivity differences dependent on sex may exist in humans (Ferdenzi et al. 2013), non-human primates (Laska et al. 2007a), and dogs (Wells and Hepper 2003). Nucleotide polymorphisms and variations in genes that express olfactory receptors may be the proximate cause of differences between the sexes. Nevertheless, the behavioral relevance (attractiveness or deterrence) of an odorant may be the ultimate cause (Laska et al. 2007a). Some gender-based olfactory sensitivity differences were determined with the use of aromatic aldehyde bourgeonal (Olsson and Laska 2010, Ferdenzi et al. 2013), but it has also been shown that olfactory thresholds are extremely variable across subjects (Stevens et al. 1988) and change substantially over time in humans. This is also the case for shorter periods (Stevens and Dadarwala 1993).

Olfactory receptors in mammals are encoded by the largest gene family charted in the mammalian genome. High number of amino acid changes is affected by high level of polymorphism, high number of pseudogenes and many allelic variants (Quignon et al. 2005, Tacher et al. 2005). Moreover, the anatomical features of intranasal volumes and the nasal cavity were found to have an influence in dogs (Damm et al. 2002). It has been proven that olfactory sensitivity also changes during an animal's lifetime, and this also applies to certain mammalian species (Doty 1989, Wells and Hepper 2003).

It has been suggested that in mammals, such as dogs, that have a very acute sense of smell, an anatomical structure called the olfactory recess determines olfactory superiority in comparison with animals, such humans that lack this structure. It has been demonstrated in the fluid dynamics of canine olfaction that a unique nasal airflow pattern develops during sniffing, which is optimized for odorant transport to the olfactory part of the nose. Thus, mammalian olfactory function and acuity may depend on the transport of odorant molecules to the olfactory recess where the odorant receptors are exposed to prolonged contact with them (Craven et al. 2010, Sobel et al. 2000). One study, which indicated that apparent sensitivity to some odorants is significantly greater at high nasal flow rates while other odorants exhibit the opposite effect, showed this connection to be contradictory. When the airflow rate and sniffing frequency in mice were evaluated separately, the nasal airflow rate, instead of the sniffing frequency, was found to affect the observed response in the olfactory glomeruli (Oka et al. 2009).
In studies conducted on olfactory sensitivity in mammalian species, the experiments focus on the capability of the studied subject to detect the target substance or to distinguish between two or more different substances. In some studies on olfactory sensitivity, the capability to detect a target odorant is considered. The methodology of individual experiments differed in the searching and marking of the target substance as well as in the chemical nature and concentration of the target substance. In recent studies, behavioral tests were used mostly to determine the odor detection threshold. The ODT is determined by testing the animals' ability to discriminate between a target odor and a blind sample that comprises an odorless object. Behavioral tests are based on instrumental conditioning and multiple-choice tests. In multiple-choice tests, the subjects must find and distinctly mark the target substance in different concentrations and are rewarded with food for the correct answer. The descending staircase procedure is usually repeated, and to mix the exact concentration of the target odorant, an odorless solvent is used in the multiplechoice test with a blind sample.

When the concentration detection function is measured, an alternative forced-choice procedure against air as a blank sample and an ascending concentration of target odor are usually used in humans. ODTs were defined as the concentration producing detectability $(\mathrm{P})$ halfway $(\mathrm{P}=0.5)$ between chance $(\mathrm{P}=0.0)$ and perfect detection $(\mathrm{P}=1.0)$. Similar procedures have been used for other mammalian experiments. The odorant concentration is generally indicated in dilute concentration units parts per million (ppm), parts per billion (ppb), and parts per trillion (ppt) and are usually used with vapor phase concentrations. In previous studies, units based on moles or percent were used and generally refer to concentrations in the liquid phase.

\section{Reported olfactory thresholds}

\section{Human}

Differences in olfactory sensitivity seem to have a genetic basis in humans as well. The olfactory threshold varies greatly across subjects. Olfactory receptors are determined by a large number of olfactory genes that display a high level of polymorphism and nonfunctional pseudogenes (Cometto-Muniz and Abraham 2008). Because human diseases are the main focus of scientific research, the influence of diseases on olfactory sensitivity in humans has been thoroughly explored in subjects with 
obsessive compulsive disorder (Browne et al. 2006), Parkinson's disease (Harper et al. 2005, Haehner et al. 2007, Wu et al. 2011), diabetes mellitus and its genetic background (Guthoff et al. 2009), dementia and Alzheimer disease (Wysocki et al. 1997), schizophrenia (Moberg et al. 1999), depression (Ferris et al. 2007, Croy et al. 2014a), and other various dysfunctions. Human emotions (Larsson et al. 2000, Brand and Millot 2001, Pause et al. 2001, Havlíček 2008) and personality (Havlíček 2012, Pause 2012) may influence olfactory perception and it has been demonstrated that strong negative emotions can reduce olfactory sensitivity (Croy et al. 2014a).

In terms of inter-sex differences studies have indicated that women outperform men in specific olfactory threshold measurements (Brand and Millot 2001, Doty and Cameron 2009). Olfactory sensitivity in women may vary within a few days, differences depending on reproductive state (Lundstrom et al. 2006) and during the menstrual cycle (Hummel et al. 1991, Doty and Cameron 2009) have been found. A review by Martinec Nováková et al. (2014) supported the notion that there is a significant cycle-correlated variation of olfactory sensitivity in women (Hummel et al. 1991). Olfactory thresholds differed significantly across the cycle; the lowest thresholds were measured during the ovulatory phase and the highest during the menstrual phase (Navarrete-Palacios et al. 2003), in a variety of odorants (social and non-social odors), regardless of their different evolutionary significance (Saxton et al. 2008, Martinec Nováková et al. 2014). These findings support the claim that changes in olfactory sensitivity are linked to a common effect in odor perception in general (Pause et al. 2006, Doty and Cameron 2009). Although sexual orientation might play a role in hypothalamus activation in putative hormones (Savic et al. 2001, Berglund et al. 2006, Savic and Lindstrom 2008), it can be explained by sexual arousal, an acquired sensitization to a specific compound (Berglund et al. 2008). It has also been repeatedly proven that olfactory sensitivity decreases with aging (Ezeh et al. 1992, Stevens and Dadarwala 1993, Hummel et al. 2007, Guthoff et al. 2009). According to numerous studies, the repeated introduction of a target odor (even in a perithreshold concentration) causes a decrease in the olfactory threshold and detection sensitivity (Doty et al. 1981, Rabin and Cain 1986, Wysocki and Gilbert 1989, Dalton et al. 2002, Mainland et al. 2002). The brain synapses strengthen with use (Jancke 2009), and everyday olfactory experiences can improve olfactory performance via long-term neuronal plasticity in the olfactory brain regions (Buschhuter et al. 2008, Frasnelli et al. 2010, Seubert et al. 2013). During an investigation in which acetone was used as a target odor, the exposure of experimental subjects to acetone decreased olfactory sensitivity. The ODTs were set at $855 \mathrm{ppm}$ in previously exposed subjects and $41 \mathrm{ppm}$ in non-exposed subjects (Wysocki et al. 1997); this was in contrast to increasing sensitivity with experience in investigation cases. This suggests exposure to some substances induces changes in sensitivity, which are specific for this substance (acetone) in particular. The odorant-specific plasticity in the olfactory system is supported by studies that used human steroids as the target odorant. A pronounced decrease in the ODTs of more than four orders of magnitude with repeated exposure was found for the human steroid androstadienone. These experience-dependent changes in threshold were accompanied by a change in perceived odor quality (Lundstrom et al. 2003). Androstenoneanosmic subjects can acquire sensitivity to this steroid hormone by repeated exposure, while subjects who are able to detect androstenone can lower their threshold with repeated exposure (Jacob et al. 2003, Wang et al. 2004).

Amyl acetate was used as a target odor when different methods (general procedure, modified constant stimuli procedure, FC-AML procedure, staircase procedure) for determining the ODT were compared. The average threshold of these methods was about $0.11 \mathrm{ppb}$ (Wise et al. 2008). In similar studies, certain ODTs were set as low as $0.29 \mathrm{ppb}$ (acetate esters) (Cometto-Muniz et al. 2008), $0.14 \mathrm{ppb}$ (aliphatic aldehydes) (Stevens et al. 1988), 2 ppm (hydrogen sulfide) and $1.9 \mathrm{ppm}$ (cis-3hexen-1-ol) (Jaeger et al. 2010), which also contain high concentration results such as $500000 \mathrm{ppm}$ for carbon dioxide or $175000 \mathrm{ppm}$ for amyl acetate. Specific ODTs for n-alcohols in humans varied from $2.52 \mathrm{ppb}$ (ethanol) to $0.64 \mathrm{ppb}$ (I-octanol) (Cometto-Muniz and Abraham 2008). A subsequent study on humans set the olfactory sensitivity threshold for different organic substances from $245 \mathrm{ppb}$ (ethyl acetate) to $2.9 \mathrm{ppb}$ (hexyl acetate) (Cometto-Muniz et al. 2008). Using 2-ketones as the target odorant, the ODT decreased from $832 \mathrm{ppb}$ (acetone) to $5.5 \mathrm{ppb}$ (nonanone) (Cometto-Muniz and Abraham 2009b). For the use of n-alkyl benzenes as a target odor, the specific detection threshold decreased from $89 \mathrm{ppb}$ (octylbenzene) to $2.5 \mathrm{ppb}$ (butylbenzene) (Cometto-Muniz and Abraham 2009a). A similar research study was conducted with aliphatic aldehydes and 
helional as the target odors, and the ODTs decreased from $2.0 \mathrm{ppb}$ (propanal) to the lowest threshold of $0.14 \mathrm{ppb}$ (octanal and helional) (Cometto-Muniz and Abraham 2010). The inter-individual threshold variability ranged between one and two orders of magnitude.

The chemesthesis threshold for pungency occurs in concentrations as low as one and as high as six orders of magnitude above the olfactory threshold (ComettoMuniz and Cain 1990, Cometto-Muniz and Hernandez 1990, Cometto-Muniz and Cain 1991, 1993, 1994). When the effect of aging on olfactory capabilities was examined, butanol was chosen as the target odor, and the olfactory threshold was set at $60000 / 1$ in elderly subjects and at $2200 / 1$ in younger subjects ( $4 \%$ solution $\mathrm{v} / \mathrm{v}$ of butanol in $\mathrm{DHOH}$ (deionized water) corresponding to $3100 \mathrm{ppm}$ in the air) (Stevens and Dadarwala 1993). Female olfactory sensitivity to various alcohols was evaluated as slightly higher than male olfactory sensitivity (Cometto-Muniz and Abraham 2008). For aldehyde bourgeonal, men were able to detect significantly lower concentrations (13 ppb) than were women (26 ppb) (Olsson and Laska 2010), but according to other odor detectability studies, gender was not a significant factor (Stevens et al. 1988). In a number of studies, interindividual variability of about one order of magnitude was found between the most and the least sensitive subjects (Cometto-Muniz et al. 2008, ComettoMuniz and Abraham 2009a,b).

Although setting the olfactory detection threshold in humans seems easier than in other mammalian species, the results of olfactory sensitivity studies differ significantly. Thus, the odor detection threshold is a function of the subject's olfactory sensitivity and the experimental method. Attention must be given to the delivery, control, and reliability of the vapor stimulus in measurements of psychometric functions. When the results with the lowest olfactory threshold set are compared, the lowest detected concentration in aliphatic alcohols and aldehydes. The comparison of individual studies is not conclusive because of the methodological differences in olfactometric and psychophysical techniques.

Although the olfactory thresholds are a function of subject sensitivity and method, only a few studies with directly comparable methods used the same subject and stimulus (Wise et al. 2008). The current trend is to present olfactory stimuli in the vapor phase (ComettoMuniz and Abraham 2008, 2010) instead of the liquid phase as in previous behavioral studies (Stevens and
Dadarwala 1993), to obtain the required concentration. The stimulus concentration is most accurate when it is presented in the vapor phase and is calculated from vapor pressures (Cometto-Muniz et al. 2003). However, vapor pressure calculated from values taken from the literature may potentially exhibit large differences depending on different literature sources (Stevens and Dadarwala 1993, Cometto-Muniz and Abraham 2010). Therefore, particular computer-controlled vapor delivery devices are currently used to generate and present olfactory stimuli (Cometto-Muniz and Abraham 2008, Cometto-Muniz et al. 2008). Gas chromatography quantification of an olfactory stimulus is an indispensable aid today (Cometto-Muniz et al. 2008, Cometto-Muniz and Abraham 2009b), but it was not used in earlier studies (Stevens and Dadarwala 1993). The constant stimuli method measures full detection function (Wise et al. 2008), while the forced-choice ascending method of limits (Lawless 2010) and the staircase method (Wysocki et al. 1997, Linschoten et al. 2001, Lotsch et al. 2004) provide a reasonable estimate of the average threshold. For individual differences, the constant stimuli method seems to outperform the ascending method (MacMillan 1991) and the staircase method (Linschoten et al. 2001, Lotsch et al. 2004), which are largely limited (Wise et al. 2008).

In the constant stimuli method, the ODT is defined as the halfway point between chance and perfect detection (Cometto-Muniz and Abraham 2008, 2009b), as detectability (detection probability) (Cometto-Muniz and Abraham 2010) or as inverse detectability (Walker et al. 2003).

\section{Non-human primates}

The sense of smell in primates has been thoroughly examined in comparison to other mammalian species, possibly because primates are closer to humans than any other species. One of the first investigation methods was tested on squirrel monkeys in as early as 1992, and in the following 20 years, various studies focusing on other non-human primate species were conducted (Hudson et al. 1992). For olfactory sensitivity, some authors label animals as either "microsmatic" or "macrosmatic"; however, according to some studies (Laska et al. 2000b, Smith et al. 2004), these terms do not seem to be valid primate descriptors.

An across-species comparison is based on the assumption that New World primates generally are more sensitive than Old World primates. Since the majority of 
primate ODT studies were performed in the same laboratory at Linköping University in Sweden, similar olfactometric and psychophysical techniques were used in these studies. The primate subjects were tested using the two-choice instrumental conditioning paradigm (Hubener and Laska 2001, Laska et al. 2003). The ODTs were determined by testing the ability to detect a target sample with increasing dilution of an odorant between odorless blank samples. Olfactory stimuli were presented in the gas phase in equimolar concentrations.

One of the first olfactory investigations in pigtailed macaques (Macaca nemestrina) determined the specific olfactory threshold for peanut iso-amyl acetate and n-pentanoic acid odors. The animals detected peanut odor in dilutions as low as 1:10 000, and for amyl acetate, the animals detected dilutions from 30000 -fold up to 30 million-fold. The olfactory sensitivity threshold for pentatonic acid ranged between concentrations of 1:30000 and 1:300 000 (Hubener and Laska 2001).

A study with n-alcohols as target odorants was then carried out in squirrel monkeys (Saimiri sciureu) and pigtail macaques (Macaca nemestrina). The animals of both species significantly detected concentrations below $1 \mathrm{ppm}$, and certain individual monkeys even demonstrated thresholds below 10 ppb (Laska and Seibt 2002a). The same methods were used for aliphatic aldehydes (Laska et al. 2003), aliphatic esters, and their isomeric forms (Laska and Seibt 2002b). With few exceptions, both species significantly determined concentrations below $1 \mathrm{ppm}$, and several animals even demonstrated thresholds below 1 ppb (Laska and Seibt 2002b, Laska et al. 2003). The detection thresholds for a homologous series of aliphatic esters and isomeric forms were also investigated in spider monkeys. The monkeys significantly detected concentrations below $1 \mathrm{ppm}$, and in several cases even below $1 \mathrm{ppb}$ (Hernandez Salazar et al. 2003). In the case of aliphatic alcohols and aldehydes, the spider monkeys were able to significantly discriminate concentrations below $1 \mathrm{ppm}$, and certain individual monkeys even demonstrated detection thresholds below 1 ppb (Laska et al. 2006b). In accordance with these results, a following comparative study about olfactory detection performance showed a high degree of similarity between the two primate species (squirrel monkeys and pigtail macaques), as well as between these non-human primates and human subjects tested in an earlier study on the same tasks (Laska et al. 2005b). Another study that used acyclic monoterpene alcohols and involved squirrel monkeys, spider monkeys (Ateles geoffroyi), and pigtail macaques (Macaca nemestrina) showed that squirrel monkeys were significantly more sensitive than the other two species; the squirrel monkeys were able to detect this class of odorants at concentrations below 0.1 ppm (Laska et al. 2006a). Nonetheless, a particular comparative investigation performed on substances with apparent behavioral relevance (characteristic of putrefaction processes and fecal odor) in spider monkeys, squirrel monkeys, and pigtail macaques did not show any significant differences among these three primate species. All animals significantly discriminated concentrations below $1 \mathrm{ppm}$, and in several cases, individual animals even demonstrated thresholds below 1 ppt. The detection thresholds for indol in squirrel monkeys and pigtailed macaques and for ethanethiol in spider monkeys represent the lowest values among more than 50 odorants tested to date. These values are in the same order of magnitude as the lowest detection thresholds that have yet to be reported rats and mice (Laska et al. 2007a).

As most of these olfactory studies (Hubener and Laska 2001, Laska and Seibt 2002a,b, Laska et al. 2003, $2005 \mathrm{a}, 2006 \mathrm{~b}, 2007 \mathrm{a})$ were conducted in the same laboratory using the same methods and animals, the threshold values are comparable with great reliability. However, there are some methodological difficulties in between-studies comparison. In two of three non-human primate species, only animals of one sex were available for testing, and the number of subjects was small. A similar methodology complication occurs in dogs studies. In contrast to dog and primate studies, the number of subjects in human and rodent studies is high. A food-reward instrumental conditioning paradigm was used in all non-human primate studies, similar to experiments in dogs and rodents (with the exception of Moulton et al. 1960, Krestel et al. 1984). Differences in methodology within one laboratory can be seen in the number of choices using the instrumental conditioning. In some studies, there was a two-choice paradigm (Laska et al. 2003) while in another study the multiple-choice paradigm was used (Laska et al. 2007a). To minimize the possibility of adaptation, between-trial intervals were important as well as the descending staircase concentration procedure (increasing dilutions). When some of the odorant classes were not water soluble, other odorless solvents (diethyl phthalate) had to be used (Laska and Seibt 2002b, Laska et al. 2003). In 
comparison to the number of human ODTs studies, odorants were presented in the liquid phase without direct conduction to the subjects' faces.

These studies demonstrated that spider monkeys, squirrel monkeys, and pigtailed macaques have a welldeveloped olfactory sensitivity for different classes of odorants, in comparison to another species classified as microsmatic. A similar methodology allows us to collate experimental results between individual species (Table 1). The results show primates are most sensitive to thiols and indols, while pigtailed macaques were the bestscoring species. In contrast, squirrel monkeys and spider monkeys outperformed when aliphatic alcohols and aldehydes were used as the target odorants.

Across-species ODT comparisons seem to support the contention that comparisons of neuroanatomical features or of the number of functional OR genes are only poor predictors of olfactory performance. The ODT studies emphasize an ecological view that tries to correlate chemosensory performance with the behavioral relevance of the subject odorant (Laska et al. 2009, 2010).

\section{Dogs}

Dogs are capable of detecting and identifying odorant molecules even in minute concentrations (Quignon et al. 2005). The sensitivity of canine olfaction is utilized in many areas, such as biological and abiological scent detection (humans, animals, plants, tobacco, accelerants, bank notes, etc.) (Browne et al. 2006). The body of papers that focus on the ability of dogs to detect different types of cancers (Welch 1990, Pickel et al. 2004, Willis et al. 2004, McCulloch et al. 2006, 2012, Horvath et al. 2008, 2010, 2013, Cornu et al. 2011, Sonoda et al. 2011, Bomers et al. 2012, Ehmann et al. 2012, Bijland et al. 2013) as well as diabetes (Dehlinger et al. 2013), cirrhosis (Bijland et al. 2013), and the first signs of an epileptic seizure (Brown and Strong 2001, Strong et al. 2002) is growing. The olfaction of dogs used as a diagnostic tool is often as accurate as, or even superior to, standard diagnostic methods. As our environment is becoming more and more polluted, dogs' sense of smell is useful in pollution and contamination detection (Partyka et al. 2014), as well as in mold and other microbial growth detection (Kauhanen et al. 2002). Despite technical advances, detection dogs are still a very effective and reliable tool in the search for drugs and explosives (Gazit et al. 2003, 2005, Gazit and Terkel 2003, Lorenzo et al. 2003,
Browne et al. 2006, Singh 2007, Irrazabal et al. 2009, Moore et al. 2012).

Dogs' ability to respond to concentrations of odorants, which humans cannot normally detect, has been widely exploited and has led to the belief that the sense of smell in dogs is far superior to that in humans. One would expect that the mechanism and sensitivity of canine olfaction have been thoroughly studied, but that is not the case (Moulton et al. 1960). Even the canine's legendary sense of smell or the growing reliance on dogs' sense of smell in relation to threats to life and property has not led to a reliable quantification of canine olfactory sensitivity (Walker et al. 2006). Despite significant efforts invested in olfaction principles studies, many unanswered questions regarding olfaction and the use of specially trained dogs remain (Harper et al. 2005). Although data derived from laboratory studies might be expected to provide reliable information about olfactory sensitivity, published values show differences that are perhaps among the most extreme reported for any sensory perception (Moulton et al. 1960). The main complication in using psychophysical methods lies in the differences in detection performance between individual dogs; these differences seem to be related to behavioral variations (Svartberg and Forkman 2002, Adamkiewicz 2013, Jezierski et al. 2014), which we can expect in other species, investigated using psychophysical tests.

A study performed by the Canine Behaviour Centre, Queens University, Belfast, showed that dogs are able to determine the direction of a track with the aid of only five individual tracks (Hepper and Wells 2005). This was the only study to date that has reported differences in olfactory sensitivity between male and female domestic dogs. Male dogs identified the correct direction of a given track more frequently than did female dogs, and younger dogs performed better than older animals (Wells and Hepper 2003). The same research team also confirmed pre- and post-natal learning regarding chemosensory stimuli in puppies (Hepper and Wells 2006). Genderspecific induction of enhanced sensitivity was found in male dogs which generally outperformed female dogs. These findings are contrary to olfactory studies in humans; studies indicate women outperform men with specific odorant substances, such as sex hormones (Brand and Millot 2001, Doty and Cameron 2009). Regardless, no reliable sex differences have been found in dogs (Wells and Hepper 2003) or in humans (Olsson and Laska 2010, Ferdenzi et al. 2013). 
Table 1. Olfactory detection thresholds for laboratory chemical substances in vapor phase in ppm concentration.

\begin{tabular}{|c|c|c|c|c|c|c|c|}
\hline Chemical class & $\begin{array}{l}\text { Chemical } \\
\text { substance }\end{array}$ & Human & $\begin{array}{c}\text { Pigtail } \\
\text { macaque }\end{array}$ & $\begin{array}{l}\text { Spider } \\
\text { monkey }\end{array}$ & $\begin{array}{l}\text { Squirrel } \\
\text { monkey }\end{array}$ & Dog & Mouse \\
\hline \multirow[t]{5}{*}{ Aliphatic alcohols } & pentanol & $\mathrm{x}$ & 0.29 & 0.0004 & 0.0004 & $\mathrm{x}$ & 0.00003 \\
\hline & hexanol & $\mathrm{x}$ & 0.006 & 0.006 & 0.006 & $\mathrm{x}$ & 0.0003 \\
\hline & heptanol & $\mathrm{x}$ & 0.0032 & 0.0003 & 0.00031 & $\mathrm{x}$ & \\
\hline & octanol & 0.00064 & 0.0048 & 0.0048 & 0.048 & $\mathrm{x}$ & \\
\hline & propanal & 0.002 & $\mathrm{x}$ & $\mathrm{x}$ & $\mathrm{x}$ & $\mathrm{x}$ & \\
\hline \multirow[t]{6}{*}{ Aliphatic aldehydes } & butanal & $\mathrm{x}$ & 0.0004 & 0.039 & 0.0039 & 0.00004 & \\
\hline & pentanal & $\mathrm{x}$ & 0.148 & 0.00148 & 0.0148 & $\mathrm{x}$ & \\
\hline & heptanal & $\mathrm{x}$ & 0.0024 & 0.00235 & 0.00235 & 0.00004 & \\
\hline & hexanal & 0.00014 & 0.00052 & 0.0052 & 0.052 & $\mathrm{x}$ & \\
\hline & ocatanal & 0.0014 & 0.0016 & 0.00016 & 0.16 & $\mathrm{x}$ & \\
\hline & burgeonal & $\mathrm{x}$ & $\mathrm{x}$ & $\mathrm{x}$ & $\mathrm{x}$ & 0.000000001 & $\mathrm{x}$ \\
\hline \multirow[t]{5}{*}{ Acetate esters } & amyl acetate & 0.00011 & 0.14 & $\mathrm{x}$ & $\mathrm{x}$ & 0.0000114 & \\
\hline & ethyl acetate & 0.245 & $\mathrm{x}$ & 0.036 & $\mathrm{x}$ & $\mathrm{x}$ & 0.0000041 \\
\hline & butyl acetate & 0.0043 & $\mathrm{x}$ & 0.00006 & $\mathrm{x}$ & $\mathrm{x}$ & \\
\hline & pentyl acetate & $\mathrm{x}$ & $\mathrm{x}$ & 0.000027 & $\mathrm{x}$ & $\mathrm{x}$ & \\
\hline & hexyl acetate & 0.0029 & $\mathrm{x}$ & 0.00013 & $\mathrm{x}$ & $\mathrm{x}$ & \\
\hline \multirow[t]{2}{*}{ Carboxylic acids } & butanoic acid & $\mathrm{x}$ & $\mathrm{x}$ & $\mathrm{x}$ & $\mathrm{x}$ & $\mathrm{x}$ & 0.000003 \\
\hline & pentanoic acid & $\mathrm{x}$ & $\mathrm{x}$ & $\mathrm{x}$ & $\mathrm{x}$ & $\mathrm{x}$ & 0.000003 \\
\hline Amid acids & panthotenic acid & $\mathrm{x}$ & 0.0019 & $\mathrm{x}$ & $\mathrm{x}$ & $\mathrm{x}$ & $\mathrm{x}$ \\
\hline Nitroalkanes & dimethyl dinitrobut. & $\mathrm{x}$ & $\mathrm{x}$ & $\mathrm{x}$ & $\mathrm{x}$ & 0.0005 & $\mathrm{x}$ \\
\hline \multirow[t]{3}{*}{ Thiols } & ethanethiol & $\mathrm{x}$ & 0.000096 & 0.00000096 & & $\mathrm{x}$ & $\mathrm{x}$ \\
\hline & butanethiol & $\mathrm{x}$ & 0.000016 & 0.00016 & 0.00016 & $\mathrm{x}$ & $\mathrm{x}$ \\
\hline & pentanethiol & $\mathrm{x}$ & 0.00063 & 0.00063 & 0.00063 & $\mathrm{x}$ & $\mathrm{x}$ \\
\hline Thiazolines & trimethylthiazoline & $\mathrm{x}$ & $\mathrm{x}$ & x & & $\mathrm{x}$ & 40.00 \\
\hline \multirow[t]{2}{*}{ Indols } & indole & $\mathrm{x}$ & 0.00000003 & 0.0003 & 0.00000003 & $\mathrm{x}$ & $\mathrm{x}$ \\
\hline & methyl indole & $\mathrm{x}$ & 0.000037 & 0.0000037 & 0.000012 & $\mathrm{x}$ & $\mathrm{x}$ \\
\hline Ketones & nonanone & 0.0055 & $\mathrm{x}$ & $\mathrm{x}$ & $\mathrm{x}$ & $\mathrm{x}$ & $\mathrm{x}$ \\
\hline Sulfides & hydrogen sulfide & 2.00 & $\mathrm{x}$ & $\mathrm{x}$ & $\mathrm{x}$ & $\mathrm{x}$ & $\mathrm{x}$ \\
\hline \multirow[t]{3}{*}{ Amino acids } & cystein & $\mathrm{x}$ & $\mathrm{x}$ & 0.0013 & $\mathrm{x}$ & 0.0000044 & $\mathrm{x}$ \\
\hline & methionine & $\mathrm{x}$ & $\mathrm{x}$ & 0.0011 & $\mathrm{x}$ & 0.000036 & $\mathrm{x}$ \\
\hline & proline & $\mathrm{x}$ & $\mathrm{x}$ & 0.002 & $\mathrm{x}$ & 0.023 & $\mathrm{x}$ \\
\hline \multirow[t]{3}{*}{ Alkylpyrazines } & pyrazine & $\mathrm{x}$ & $\mathrm{x}$ & 27.80 & $\mathrm{x}$ & 0.028 & $\mathrm{x}$ \\
\hline & methyl pyrazine & $\mathrm{x}$ & $\mathrm{x}$ & 0.044 & $\mathrm{x}$ & 0.0001 & $\mathrm{x}$ \\
\hline & tetramethyl pyr. & $\mathrm{x}$ & $\mathrm{x}$ & 0.00063 & $\mathrm{x}$ & 0.00000092 & $\mathrm{x}$ \\
\hline \multirow[t]{3}{*}{ Benzenes } & butylbenzene & 0.00025 & $\mathrm{x}$ & $\mathrm{x}$ & $\mathrm{x}$ & $\mathrm{x}$ & $\mathrm{x}$ \\
\hline & octylbenzene & 0.00029 & $\mathrm{x}$ & $\mathrm{x}$ & $\mathrm{x}$ & $\mathrm{x}$ & $\mathrm{x}$ \\
\hline & propylthietane & 0.0000000059 & $\mathrm{x}$ & $\mathrm{x}$ & $\mathrm{x}$ & $\mathrm{x}$ & $\mathrm{x}$ \\
\hline \multirow[t]{5}{*}{$\begin{array}{l}\text { Sulfur-containing } \\
\text { volatiles }\end{array}$} & methylbutyl form. & 0.0000000013 & $\mathrm{x}$ & $\mathrm{x}$ & $\mathrm{x}$ & $\mathrm{x}$ & $\mathrm{x}$ \\
\hline & propylthiethane & & $\mathrm{x}$ & 0.0000074 & $\mathrm{x}$ & 0.00003 & $\mathrm{x}$ \\
\hline & butanethiol & 0.00000052 & $\mathrm{x}$ & 0.0000026 & $\mathrm{x}$ & 0.00000003 & $\mathrm{x}$ \\
\hline & phenylethyl sulfide & 0.0000016 & $\mathrm{x}$ & 0.0000012 & $\mathrm{x}$ & 0.00000003 & $\mathrm{x}$ \\
\hline & methylbuthyl form. & & $\mathrm{x}$ & 0.0000052 & $\mathrm{x}$ & 0.000003 & $\mathrm{x}$ \\
\hline Oxides & carbon dioxide & $\mathrm{x}$ & $\mathrm{x}$ & $\mathrm{x}$ & $\mathrm{x}$ & $\mathrm{x}$ & 700.00 \\
\hline
\end{tabular}


Olfactory sensitivity may also differ between dog breeds. When the additional olfactory receptor gene polymorphism was identified in 20 various breeds, some mutations were found to be breed-specific (Quignon et al. 2005, Tacher et al. 2005). No study has been published that compared the olfactory thresholds of various dog breeds. A recent study that compared the olfactory performance of Pugs, German Shepherds, and Greyhounds did not determine their ODT either; nevertheless, in an experiment in which the dogs were supposed to alert to various dilutions of the target odor, Pugs significantly outperformed German Shepherds while Greyhounds could not be tested because of a lack of motivation (Hall et al. 2015).

The first investigations dealing with canine olfactory sensitivity compared humans and dogs. According to the earliest studies, olfaction sensitivity in dogs is much better than that of humans (Neuhaus 1953, Laska et al. 2008a). The next two investigations revealed that the olfaction sensitivity in canines was approximately the same as that in humans (Nicollini 1954, Becker 1962). A later study found that the olfaction sensitivity in dogs was approximately 100 times greater than that in humans (Moulton et al. 1960). However, the previously mentioned publications (Neuhaus 1953, Ashton 1957, Moulton et al. 1960, Krestel et al. 1984) do not provide data that may be relied upon with confidence (Walker et al. 2006).

One of the first studies on the olfactory threshold in dogs was conducted by Neuhaus (1953) and compared dogs and humans. The olfactory threshold in dogs for butyric acid and acetic acid was $8 \log$ units below that in humans. Another study, which compared specific olfactory thresholds in dogs and humans, was conducted by Kaise (1969). The olfactory threshold in dogs for clove oil was estimated at approximately $6 \log$ units below that in humans (Laska et al. 2008a). The canine ability to detect $n$-aliphatic acids was investigated by Ashton et al. (1957). The results showed individual differences in two dogs. Performance also varied with the target substances depending on the number of carbon atoms in the molecules of both acid groups. The detectable concentrations were approximately 1.54-0.801 log units of molar concentration.

The results of other studies (Nicollini 1954, Becker 1962) performed on dogs differed considerably. Canine and human olfaction sensitivity was compared again, and the results showed that dogs and humans had the same level of olfaction sensitivity. Three years later,
Moulton et al. (1960) noted canine olfaction sensitivity was $2 \log$ units below that of humans. The study was carried out with only two Labrador hybrids, and a specific olfactory threshold was determined for fatty acids. The results showed significant differences between the two dogs tested but also between the sensitivity of the two fatty acid groups. A later study by Marshall and Moulton (1981) reported similar results. The canine olfaction threshold was found to be 2-4 log units below that of humans. Krestel et al. (1984) also conducted a study focused on the comparison of olfaction in dogs and humans, but the results determined a specific threshold for amyl acetate. The dogs were trained to put their heads into a wooden box, into which the odorant was released. The dogs (six Beagles) were motivated and rewarded with water (deprivation by thirst) and punished with an electrical shock. The results presented a specific canine olfactory threshold $2.6 \mathrm{log}$ units lower than that of humans.

About 20 years later, Pickel et al. (2004) studied a specific olfactory canine threshold for amyl acetate while dealing with disease diagnostics. He observed surprising values, and the olfactory threshold was set to a concentration of about 1-2 ppt. The next study investigating olfactory sensitivity in dogs was conducted by Walker et al. (2006). The target odorant was the same substance that was used by Krestel et al. (1984), i.e. amyl acetate. In a relatively small sample of only two dogs (a Schnauzer and a Rottweiler), they found remarkable values (1.9 and $1.14 \mathrm{ppt})$ that were roughly 30 to 20000 times lower than the range of thresholds reported in previous studies (Krestel et al. 1984). Walker et al. (2006) believed their method "find the target", which is based on positive conditioning and includes more natural and non-restrictive conditions outside the laboratory, is the main cause of the difference between their study and studies that use "more conventional methods". These results indicate that canine olfactory sensitivity may be much higher than previously thought (Walker et al. 2006).

Dogs that received steroids exhibited a significant elevation in their detection threshold for benzaldehyde and eugenol, and thus it seems that olfactory acuity could also be influenced by hormones (Ezeh et al. 1992).

Studies dealing with canine sensitivity in detecting explosive substances are very rarely published. One of the few studies conducted by the Institute for Biological Detection Systems at Auburn University 
identified the specific olfactory thresholds for methyl benzoate, cyclohexanone, and nitroglycerin as ranging from ppb to ppt units (Johnston 1999). Laboratory workers from the Bureau of Alcohol, Tobacco and Firearms found that dogs were able to respond to nitromethane diluted in water in concentrations of one to one trillion. However, much lower concentrations were also mentioned in this study (Kury and Strobel 2003). Adequate olfactometry and behavioral control is often lacking in canine olfactory sensitivity studies. However, differences in the design methodologies of canine olfactory sensitivity studies may produce inaccurate comparisons (Johnston 1999).

The results of ODT studies are essentially incomparable. A small number of olfactory sensitivity experiments in dogs were conducted over a long period, and the olfactometric and psychophysical techniques differed substantially. Single experiments focused on different target odorants, and various dog breeds were used as experimental subjects. Unequal behavioral testing was applied, and the preparation of the odorant sample differed across studies, as well as odorant dilution devices. Moreover, the results were often published as a comparison with humans and described only the difference, without a specific concentration. In general, ODTs in dogs were distinctly the lowest when amyl acetate was used as a target odorant (Walker et al. 2006) although the author himself admits the possibility that it is caused by their new methodology.

Similar to other ODT psychophysical experiments, most substantial between-studies differences are found in olfactometer design and test procedure. Descending concentration testing can enhance the absorption effect and provoke olfactory adaptation, so ascending concentration testing is usually preferred (Gostelow et al. 2001). As in non-human primate psychophysical experiments, dog experiments are based on operation conditioning; however, in contrast with olfactory studies in primates, the odorant dilution devices differ (Shepherd 2004, Craven et al. 2010). A substantial difference in methodologies can be found even between experimental designs of canine studies and huge differences in results in ODT concentrations spring there. According to the latest experimental approaches, the absence of any deprivation during training (physical pain, lack of water or food), as well as the method of target odorant detection (stationary odorant chambers or active finding of the target), causes differences in orders of units (Walker et al. 2006, Craven et al. 2009). Ascending staircase (decreasing dilution) of odorant concentration is always used in canine experiments, as well as in primates, but the emphasis is placed on the piecemeal descending staircase (increasing dilution) of the concentration to avoid olfactory adaptation by the subjects (Walker et al. 2006).

\section{Rodents}

Rats (Rattus rattus) have a highly developed ability to detect and identify odorants in minimal concentrations (Quignon et al. 2005). Although, to date, sniffer dogs remain a still indispensable and very effective means of explosive detection (Moore et al. 2012), African giant pouched rats (Cricetomys gambianus) have been trained to detect buried landmines (Corcelli et al. 2010, Poling et al. 2011) and are able to detect tuberculosis (Mahoney et al. 2012, Mgode et al. 2012). One of the basic factors influencing olfactory acuity is the animal's feeding state. According to a study by Aime et al. (2007), food-deprived rats exhibited increased detection at low concentrations, which led to the conclusion that olfactory sensitivity increases in food-deprived animals (Aime et al. 2007). Olfactory performance improves with repeated exposure to a particular substance in other mammalian species as well as in rats (Doty and Ferguson-Segall 1989, Wilson 2000, Wilson and Stevenson 2003) and mice (Wang et al. 1993, Yee and Wysocki 2001). One of the first olfactory sensitivity studies performed in mice (Mus musculus) focused on the absolute detection threshold for ethyl acetate, which was set below 0.41 ppt. When the same methods are used, this value is similar to that obtained in rats (Rattus rattus) (Dalton et al. 2002). Laska et al. (2007b) investigated the ability of discrimination between odorant pairs, first with homologous series of aliphatic aldehydes. The animals were able to discriminate between two odorant pairs when the stimuli were presented at concentrations of $1.00,0.01$, and $0.001 \mathrm{ppm}$, and mice also have an excellent ability to discriminate between structurally related aliphatic odorants. The mice were also able to distinguish between 50 stimuli that were presented at a gas phase concentration of $1 \mathrm{ppm}$. The same laboratory later examined the ODTs, and aromatic aldehydes were used as the first target odorants. When all seven stimuli were considered, the mice detected concentrations as low as $0.01 \mathrm{ppm}$ from the solvent, and with bourgeonal, the animals detected concentrations as low as 0.1 parts per quadrillion, which constitutes the lowest olfactory detection threshold value reported in this 
species to date (Larsson and Laska 2011).

In a subsequent study, eight structurally related aliphatic C-6 alcohols and aldehydes were used as the target odorant, and all mice detected concentrations below $0.03 \mathrm{ppm}$. With three of the substances, the bestscoring animals were even able to detect concentrations below 0.03 ppb (Laska et al. 2008a). Further comparisons suggest that odor structure-activity relationships are substance class-specific and species-specific (Can Guven and Laska 2012).

ODT studies in rats have also presented results as volume percentages, which make it difficult to compare these studies with previous studies. The detection threshold for $\mathrm{CO}_{2}$ was estimated at about 700 ppm (Ferris et al. 2007).

When microsmatic and macrosmatic mammalian species were compared, mice or rats were used as the subject organism several times in the psychophysical laboratory of Linköping University in Sweden, which make the results at least partially comparable (Table 1). The same methodological principles were a significant advantage in rodent experiments (almost exclusively in mice), similar methodologies found in non-human primates, but lacking in other mammalian ODT studies. The same methodological rules were followed by using automated liquid-dilution olfactometer, near-odorless diethyl phthalate as a solvent, the instrumental conditioning procedure, and the increasing dilution of the target odorant. An important point is the choice of experimental subjects: an outbred strain of mice was used for the experiments as the mice's genetic background is more similar to wild-type mice than that of inbred strains (Laska et al. 2007b, Laska et al. 2008a, Larsson and Laska 2011, Can Guven and Laska 2012). In rats, target odorants were chosen to investigate the behavioral context, and the results suggested the behavioral relevance of an odorant plays an important role as a determinant of a species' olfactory sensitivity. The across-species experiments in mice allow us to compare the ODT concentrations with some other mammalian species, primarily non-human primates. In general, mice are more sensitive to alkyl pyrazines, amino acids, and aliphatic esters and to aliphatic aldehydes, where the lowest ODT values were reported in this species thus far. Mice were able to detect smaller concentrations than nonhuman primates when six sulfur-containing volatiles known as components of the odors of natural predators of the mouse were used. When aliphatic alcohols are used, the ODTs in mice are equal to ODTs in humans and non- human primates.

\section{Other mammalian species}

In other mammalian species, olfactory sensitivity research is lacking substantially and is mostly confined to studies focused on a number of olfactory cues the subject can easily distinguish. Studies have investigated the South African fur seal (Arctocephalus pusillus) (Laska et al. 2008b, Laska et al. 2010), the Asian elephant (Elephas maximus) (Arvidsson et al. 2012), and the short-nosed fruit bat (Cynopterus sphinx) (Ganesh et al. 2010, Zhang et al. 2013). Studies dealing with olfactory detection thresholds in other mammalian species are very rare. The only study of greater significance was carried out using Göttingen minipigs (Sus scrofa domestica). The ODTs for ethyl acetate and ethanol were determined as a concentration as low as 5 ppm (Sondergaard et al. 2010), which is far from the lowest ODT reported in other mammalian species, but it is important to point out the inconsistencies in methodology. As experiments in these species are still in their infancy, they are focused on the ability of determination, in contrast with olfactory threshold experiments in primates, dogs, or rodents. Therefore, a between-species olfactory sensitivity comparison based on these studies is not possible.

\section{Between species comparison}

The quantitative structure-activity relationship (QSAR) is clearly described by Cometto-Muniz and Abraham (2008, 2009a,b, 2010) and Cometto-Muniz et al. (2008) and a significant positive correlation between ODTs and carbon chain length was found in other mammalian species (Laska and Teubner 1998, Laska et al. 2000a, 2008a, Laska and Hubener 2001, Laska 2005, Arvidsson et al. 2012, Can Guven and Laska 2012). In an inter-species comparison study that used six sulfurcontaining components of odors of natural mice predators, 12 subjects were able to detect concentrations below $0.01 \mathrm{ppm}$; when four of these odorants were used, the best-scoring subjects were able to detect even concentrations below 10 ppt. In this study, the mice were more sensitive to the tested odorants, and olfactory sensitivity did not differ substantially among the human subjects.

The evidence of a low specific olfactory threshold in squirrel monkeys and humans for carboxylic acids was provided and supports the assumption that human and non-human primates may share common 
principles of odor quality perception (Laska and Teubner 1998). Another investigation that compared non-human primates and rodents was performed with substances with apparent behavioral relevance (characteristic of putrefaction processes and fecal odor) in spider monkeys, squirrel monkeys, and pigtail macaques. No significant differences between these three primate species were found. All animals significantly discriminated concentrations below $1 \mathrm{ppm}$, and in several cases, individual animals even demonstrated thresholds below 1 ppt. The ODTs for indol in squirrel monkeys and pigtailed macaques and for ethanethiol in spider monkeys represent the lowest values among more than 50 odorants tested to date. These values are in the same order of magnitude as the lowest detection thresholds that have yet to be reported in rats and mice (Laska et al. 2007a). Next, a study testing primates and mice was conducted with three female spider monkeys. They were able to detect aliphatic alcohols and aldehydes at concentrations below $1 \mathrm{ppm}$, and six of the eight stimuli were detected at concentrations below $0.1 \mathrm{ppm}$ by the animals with the highest olfactory sensitivity. Mice even outperformed non-human primates with ODTs for aliphatic alcohols below $0.01 \mathrm{ppm}$ (Lotvedt et al. 2012).

The behavioral relevance of trimethylthiazoline (a volatile component of the anal gland secretion of the red fox) was the main issue of between-species comparison between rats and three primate species. The three primate species, which are all non-prey species of the red fox, were able to detect concentrations in ppb units, which do not rank among the lowest olfactory thresholds reported for these species. Rats, a natural prey species of the red fox, were able to discriminate concentrations between 0.04 and $0.10 \mathrm{ppt}$, which is by far the lowest olfactory detection threshold for an odorant reported in rats to date (Laska et al. 2005a).

Olfactory sensitivity for alkyl pyrazines in mice and spider monkeys was tested in a comparative study (Laska et al. 2009). The spider monkeys were able to detect five stimuli at concentrations below $1 \mathrm{ppm}$, and with one stimulus, they were able to identify concentrations even below $1 \mathrm{ppb}$. With all six alkyl pyrazine stimuli, mice were able to detect concentrations below or equal to $0.1 \mathrm{ppm}$, with the best-scoring individuals detecting concentrations below or equal to $0.1 \mathrm{ppb}$; these results indicate that mice may be more sensitive than spider monkeys. Another comparison of the detection thresholds between mice and spider monkeys was performed for three amino acids. The best- performing spider monkeys detected concentrations below $1 \mathrm{ppb}$. All the mice detected concentrations equal to or below $0.1 \mathrm{ppm}$, and the best-scoring animals were able to detect concentrations even below $0.1 \mathrm{ppb}$ (Wallen et al. 2012). The results of these two studies indicated that mice were more sensitive than spider monkeys. In an additional comparison study that included humans, spider monkeys, and mice, six sulfur-containing components of the odors of natural predators of mice were used as target odors. The spider monkeys were able to detect concentrations below $0.01 \mathrm{ppm}$, and four of these odorants were detected at concentrations below $10 \mathrm{ppt}$ by the animals with the highest olfactory sensitivity. In this study, the mice proved to be more sensitive to the experimental odorants; however, the human subjects did not differ significantly.

When olfactory detection thresholds for seven aromatic aldehydes were determined, no general differences between olfactory sensitivity in humans and that of spider monkeys were observed (Kjeldmand et al. 2011). Both species detected concentrations lower than $1 \mathrm{ppm}$ for all odorants, and certain individuals even distinguished concentrations lower than $1 \mathrm{ppb}$ for several odorants.

These results support the assumption that the behavioral relevance of an odorant may be an important determinant of a particular species' olfactory sensitivity. In the future, it might be useful to select target substances used in ODT comparisons by their behavioral relevance to each of the investigated species.

\section{Conclusions}

As a result of intensive research activities in physiology, genetics, anatomy, and behavior, knowledge surrounding the mechanisms underlying olfactory perception has increased significantly within the last two decades. Nevertheless, many questions remain open despite the immense progress made. Among these questions are those that deal with olfactory thresholds and olfactory system sensitivity. Physiological principles that determine a specific olfactory sensitivity are still unclear, and after several papers that deal with the behavioral testing of various mammalian species were reviewed, it is still not possible to conclude which anatomical or physiological characteristics are responsible for higher or lower thresholds to specific substances.

An overview of olfactory sensitivity in most studied mammalian species is presented here, together 
with basics of olfactory perception and olfactory sensitivity factors. The results of the more than 40 studies presented provide further evidence of low specific olfactory thresholds in mammalian species. These research findings lend further support to the suggestion that genetic or neuroanatomical between-species comparison cannot be taken as a reliable predictor of olfactory performance.

According to the current research developments, scientific attention is increasingly focused on how olfactory sensitivity changes are associated with diagnosis of human diseases (Wu et al. 2011, Guthoff et al. 2009, Moberg et al. 1999, Croy et al. 2014b). The rise of this field of study is closely related to the development of high-resolution magnetic resonance (Welge-Lussen et al. 2009, Toledano et al. 2012, Croy et al. 2014c) and event-related potentials recording (Kayser et al. 2011). Another rapidly developing research area is closely linked to the between-species comparisons described in this review, and investigations focused on olfactory gene expression (Quignon et al. 2005, Tacher et al. 2005) not only in mammals (Laberge and Hara 2004).
As is made clear in this article, no studies have demonstrated a direct connection between olfactory sensitivity and an absolute number of specific olfactory receptors, the density of ORs in the olfactory epithelium, or the size and quality of the olfactory structures in the brain. An ecological view of olfactory sensitivity correlated with the behavioral relevance of odor stimuli offers a future approach in the significance of olfaction in mammalian species. The detectability of odorants may also be affected by their behavioral relevance and frequency of occurrence in the environment of the receiving subject. Future behavioral research in the field of specific olfactory sensitivity should focus on differences associated with species, breeds, sex, previous exposure, and behavioral relevance. A uniform comparable methodology of etho-physiological experiments has not been introduced. In the future, more integration of component studies should be followed, leading to a uniform methodological approach.

\section{Conflict of Interest}

There is no conflict of interest.

\section{References}

ABRAHAM U, SALEH M, KRAMER A: Odor is a time cue for circadian behavior. J Biol Rhythm 28: 26-37, 2013. ADAMKIEWICZ E, JEZIERSKI T, WALCZAK M, GORECKA-BRUZDA A, SOBCZYNSKA M, PROKOPCZYK M, ENSMINGER J: Traits of drug and explosives detection in dogs of two breeds as evaluated by their handlers and trainers. Anim Sci Pap Rep 31: 205-217, 2013.

AIME P, DUCHAMP-VIRET P, CHAPUT MA, SAVIGNER A, MAHFOUZ M, JULLIARD AK: Fasting increases and satiation decreases olfactory detection for a neutral odor in rats. Behav Brain Res 179: 258-264, 2007.

ARVIDSSON J, AMUNDIN M, LASKA M: Successful acquisition of an olfactory discrimination test by Asian elephants, Elephas maximus. Physiol Behav 105: 809-814, 2012.

ASHTON EH, EAYRS JT, MOULTON DG: Olfactory acuity in the dog. Nature 179: 1069-1070, 1957.

BECKER R, KING JE, MARKEE JE: Studies on olfactory discrimination in dogs: II. Discriminatory behavior in a free environment. J Com Physiol Psychol 5: 773-780, 1962.

BERGLUND H, LINDSTROM P, SAVIC I: Brain response to putative pheromones in lesbian women. Proc Natl Acad Sci U S A 103: 8269-8274, 2006.

BERGLUND H, LINDSTROM P, DHEJNE-HELMY C, SAVIC I: Male-to-female transsexuals show sex-atypical hypothalamus activation when smelling odorous steroids. Cereb Cortex 18: 1900-1908, 2008.

BIJLAND LR, BOMERS MK, SMULDERS YM: Smelling the diagnosis: a review on the use of scent in diagnosing disease. Neth J Med 71: 300-307, 2013.

BLOCK E, JANG S, MATSUNAMI H, SEKHARAN S, DETHIER B, ERTEM MZ, GUNDALA S, PAN Y, LI S, LI Z, LODGE SN, OZBIL M, JIANG H, PENALBA SF, BATISTA VS, ZHUANG H: Impalusibility of the vibrational theory of olfaction. Proc Natl Acad Sci U S A 112: E2766-E2774, 2015.

BOEHM N, GASSER B: Sensory receptor-like cells in the human foetal vomeronasal organ. Neuroreport 4: 867-870, 1993.

BOMERS MK, VAN AGTMAEL MA, LUIK H, VAN VEEN MC, VANDENBROUCKE-GRAULS CM, SMULDERS YM: Using a dog's superior olfactory sensitivity to identify Clostridium difficile in stools and patients: proof of principle study. BMJ 345: e7396, 2012. 
BRAND G, MILLOT JL: Sex differences in human olfaction: between evidence and enigma. $Q J$ Exp Psychol B 54: 259-270, 2001.

BRECHBUHL J, KLAEY M, MOINE F, BOVAY E, HURNI N, NENNIGER-TOSATO M, BROILLET MC: Morphological and physiological species-dependent characteristics of the rodent Grueneberg ganglion. Front Neuroanat 8: 87, 2014.

BRENNAN PA: Pheromones in mammalian behavior. In: The Neurobiology of Olfaction. MENINI A (ed.), CRC Press, Cambridge, 2010, pp 157-181.

BROWN SW, STRONG V: The use of seizure-alert dogs. Seizure 10: 39-41, 2001.

BROWNE C, STAFFORD K, FORDHAM R: The use of scent-detection dogs. Ir Vet J 59: 97-100, 2006.

BUSCHHUTER D, SMITKA M, PUSCHMANN S, GERBER JC, WITT M, ABOLMAALI ND, HUMMEL T: Correlation between olfactory bulb volume and olfactory function. Neuroimage 42: 498-502, 2008.

CAIN WS: Testing olfaction in a clinical setting. Ear Nose Throat J 68: 316, 322-318, 1989.

CAN GUVEN S, LASKA M: Olfactory sensitivity and odor structure-activity relationships for aliphatic carboxylic acids in CD-1 mice. PloS One 7: e34301, 2012.

COMETTO-MUNIZ JE, ABRAHAM MH: Human olfactory detection of homologous n-alcohols measured via concentration-response functions. Pharmacol Biochem Behav 89: 279-291, 2008.

COMETTO-MUNIZ JE, ABRAHAM MH: Olfactory detectability of homologous n-alkylbenzenes as reflected by concentration-detection functions in humans. Neuroscience 161: 236-248, 2009a.

COMETTO-MUNIZ JE, ABRAHAM MH: Olfactory psychometric functions for homologous 2-ketones. Behav Brain Res 201: 207-215, 2009b.

COMETTO-MUNIZ JE, ABRAHAM MH: Odor detection by humans of lineal aliphatic aldehydes and helional as gauged by dose-response functions. Chem Senses 35: 289-299, 2010.

COMETTO-MUNIZ JE, CAIN WS: Thresholds for odor and nasal pungency. Physiol Behav 48: 719-725, 1990.

COMETTO-MUNIZ JE, CAIN WS: Nasal pungency, odor, and eye irritation thresholds for homologous acetates. Pharmacol Biochem Behav 39: 983-989, 1991.

COMETTO-MUNIZ JE, CAIN WS: Efficacy of volatile organic compounds in evoking nasal pungency and odor. Arch Environ Health 48: 309-314, 1993.

COMETTO-MUNIZ JE, CAIN WS: Sensory reactions of nasal pungency and odor to volatile organic compounds: the alkylbenzenes. Am Ind Hyg Assoc J 55: 811-817, 1994.

COMETTO-MUNIZ JE, HERNANDEZ SM: Odorous and pungent attributes of mixed and unmixed odorants. Percept Psychophys 47: 391-399, 1990.

COMETTO-MUNIZ JE, CAIN WS, ABRAHAM MH: Quantification of chemical vapors in chemosensory research. Chem Senses 28: 467-477, 2003.

COMETTO-MUNIZ JE, CAIN WS, ABRAHAM MH, GIL-LOSTES J: Concentration-detection functions for the odor of homologous n-acetate esters. Physiol Behav 95: 658-667, 2008.

CORCELLI A, LOBASSO S, LOPALCO P, DIBATTISTA M, ARANEDA R, PETERLIN Z, FIRESTEIN S: Detection of explosives by olfactory sensory neurons. J Hazard Mater 175: 1096-1100, 2010.

CORNU JN, CANCEL-TASSIN G, ONDET V, GIRARDET C, CUSSENOT O: Olfactory detection of prostate cancer by dogs sniffing urine: a step forward in early diagnosis. Eur Urol 59: 197-201, 2011.

COUREAUD G, LANGLOIS D, SICARD G, SCHAAL B: Newborn rabbit responsiveness to the mammary pheromone is concentration-dependent. Chem Senses 29: 341-350, 2004.

CRAVEN BA, PATERSON EG, SETTLES GS: The fluid dynamics of canine olfaction: unique nasal airflow patterns as an explanation of macrosmia. $J R$ Soc Interface 7: 933-943, 2010.

CROY I, SYMMANK A, SCHELLONG J, HUMMEL C, GERBER J, JORASCHKY P, HUMMEL T: Olfaction as a marker for depression in humans. $J$ Affect Disord 160: 80-86, 2014a.

CROY I, NORDIN S, HUMMEL T: Olfactory disorders and quality of life - an updated review. Chem Senses 39: 185-194, 2014b.

CROY I, SCHULZ M, BLUMRICH A, HUMMEL C, GERBER J, HUMMEL T: Human olfactory lateralization requires trigeminal activation. Neuroimage 98: 289-295, 2014c. 
CROY I, ZEHNER C, LARSSON M, ZUCCO GM, HUMMEL T: Test-retest reliability and validity of the Sniffin'TOM odor memory test. Chem Senses 40: 173-179, 2015.

DALTON P, DOOLITTLE N, BRESLIN PA: Gender-specific induction of enhanced sensitivity to odors. Nat Neurosci 5: 199-200, 2002.

DAMM M, VENT J, SCHMIDT M, THEISSEN P, ECKEL HE, LOTSCH J, HUMMEL T: Intranasal volume and olfactory function. Chem Senses 27: 831-839, 2002.

DEHLINGER K, TARNOWSKI K, HOUSE JL, LOS E, HANAVAN K, BUSTAMANTE B, AHMANN AJ, WARD WK: Can trained dogs detect a hypoglycemic scent in patients with type 1 diabetes? Diabetes Care 36: e98-e99, 2013.

DOTY RL: Influence of age and age-related diseases on olfactory function. Ann N Y Acad Sci 561: 76-86, 1989.

DOTY RL, CAMERON EL: Sex differences and reproductive hormone influences on human odor perception. Physiol Behav 97: 213-228, 2009.

DOTY RL, FERGUSON-SEGALL M: Influence of adult castration on the olfactory sensitivity of the male rat: a signal detection analysis. Behav Neurosci 103: 691-694, 1989.

DOTY RL, SNYDER PJ, HUGGINS GR, LOWRY LD: Endocrine, cardiovascular, and psychological correlated of olfactory sensitivity changes during the human menstrual cycle. J Comp Physiol Psychol 95: 45-60, 1981.

DUCHAMP-VIRET P, DUCHAMP A, SICARD G: Olfactory discrimination over a wide concentration range. Comparison of receptor cell and bulb neuron abilities. Brain Res 517: 256-262, 1990.

DYSON GM: The scientific basis of odour. Chem Ind 57: 647-651, 1938.

EHMANN R, BOEDEKER E, FRIEDRICH U, SAGERT J, DIPPON J, FRIEDEL G, WALLES T: Canine scent detection in the diagnosis of lung cancer: revisiting a puzzling phenomenon. Eur Respir J 39: 669-676, 2012.

EZEH PI, MYERS LJ, HANRAHAN LA, KEMPPAINEN RJ, CUMMINS KA: Effects of steroids on the olfactory function of the dog. Physiol Behav 51: 1183-1187, 1992.

FERDENZI C, ROBERTS SC, SCHIRMER A, DELPLANQUE S, CEKIC S, PORCHEROT C, CAYEUX I, SANDER D, GRANDJEAN D: Variability of affective responses to odors: culture, gender, and olfactory knowledge. Chem Senses 38: 175-186, 2013.

FERRIS KE, CLARK RD, COATES EL: Topical inhibition of nasal carbonic anhydrase affects the $\mathrm{CO}_{2}$ detection threshold in rats. Chem Senses 32: 263-271, 2007.

FIRESTEIN S: How the olfactory system makes sense of scents. Nature 413: 211-218, 2001.

FRASNELLI J, LUNDSTROM JN, BOYLE JA, DJORDJEVIC J, ZATORRE RJ, JONES-GOTMAN M: Neuroanatomical correlates of olfactory performance. Exp Brain Res 201: 1-11, 2010.

FRASNELLI J, LUNDSTROM JN, BOYLE JA, KATSARKAS A, JONES-GOTMAN M: The vomeronasal organ is not involved in the perception of endogenous odors. Hum Brain Mapp 32: 450-460, 2011.

FRATER G, BAJGROWICZ JA, KRAFT P: Fragrance chemistry. Tetrahedron 54: 7633-7703, 1998.

GANESH A, BOGDANOWICZ W, HAUPT M, MARIMUTHU G, RAJAN KE: Role of olfactory bulb serotonin in olfactory learning in the greater short-nosed fruit bat, Cynopterus sphinx (Chiroptera: Pteropodidae). Brain Res 1352: 108-117, 2010.

GAZIT I, TERKEL J: Explosives detection by sniffer dogs following strenuous physical activity. Appl Anim Behav Sci 81: 149-161, 2003.

GAZIT I, LAVNER Y, BLOCH G, AZULAI O, GOLDBLATT A, TERKEL J: A simple system for the remote detection and analysis of sniffing in explosives detection dogs. Behav Res Methods Instrum Comput 35: 82-89, 2003.

GAZIT I, GOLDBLATT A, TERKEL J: The role of context specificity in learning: the effects of training context on explosives detection in dogs. Animal $\operatorname{Cogn}$ 8: 143-150, 2005.

GIANNARIS EL, CLELAND TA, LINSTER C: Intramodal blocking between olfactory stimuli in rats. Phys Behav 75: 717-722, 2002.

GOSTELOW P, PARSONS SA, STUETZ RM: Odour measurements for sewage treatment works. Water Res 35: 579-597, 2001.

GUTHOFF M, TSCHRITTER O, BERG D, LIEPELT I, SCHULTE C, MACHICAO F, HAERING HU, FRITSCHE A: Effect of genetic variation in Kv1.3 on olfactory function. Diabetes Metab Res Rev 25: 523-527, 2009. 
HAEHNER A, HUMMEL T, HUMMEL C, SOMMER U, JUNGHANNS S, REICHMANN H: Olfactory loss may be a first sign of idiopathic Parkinson's disease. Mov Disord 22: 839-842, 2007.

HALL NJ, GLENN K, SMITH DW, WYNNE CD: Performance of Pugs, German Shepherds, and Greyhounds (Canis lupus familiaris) on an odor-discrimination task. J Comp Psychol 129: 237-246, 2015.

HARPER RJ, ALMIRALL JR, FURTON KG: Identification of dominant odor chemicals emanating from explosives for use in developing optimal training aid combinations and mimics for canine detection. Talanta 67: 313-327, 2005.

HAVLÍČEK J, SAXTON TK, ROBERTS SC, JOZÍFKOVÁ E, LHOTA S, VALENTOVA J, FLEGR J: He sees, she smells? Male and female reports of sensory reliance in mate choice and non-mate choice contexts. Pers Individ Dif 45: 565-570, 2008.

HAVLÍČEK J, NOVÁKOVÁ L, VONDROVÁ M, KUBĚNA A, VALENTOVÁ J, ROBERTS SC: Olfactory perception is positively linked to anxiety in young adults. Perception 41: 1246-1261, 2012.

HAWKES CH, DOTY RL: Anatomy and physiology. In: The Neurobiology of Olfaction. HAWKES CH, DOTY RL (eds), Cambrige University Press, Cambridge, 2009, pp 1-59.

HEPPER PG, WELLS DL: How many footsteps do dogs need to determine the direction of an odour trail? Chem Senses 30: 291-298, 2005.

HEPPER PG, WELLS DL: Perinatal olfactory learning in the domestic dog. Chem Senses 31: 207-212, 2006.

HERNANDEZ SALAZAR LT, LASKA M, RODRIGUEZ LUNA E: Olfactory sensitivity for aliphatic esters in spider monkeys (Ateles geoffroyi). Behav Neurosci 117: 1142-1149, 2003.

HORVATH G, JARVERUD GA, JARVERUD S, HORVATH I: Human ovarian carcinomas detected by specific odor. Integr Cancer Ther 7: 76-80, 2008.

HORVATH G, ANDERSSON H, PAULSSON G: Characteristic odour in the blood reveals ovarian carcinoma. BMC Cancer 10: 643, 2010.

HORVATH G, ANDERSSON H, NEMES S: Cancer odor in the blood of ovarian cancer patients: a retrospective study of detection by dogs during treatment, 3 and 6 months afterward. BMC Cancer 13: 396, 2013.

HUBENER F, LASKA M: A two-choice discrimination method to assess olfactory performance in pigtailed macaques, Macaca nemestrina. Phys Behav 72: 511-519, 2001.

HUDSON R: From molecule to mind: the role of experience in shaping olfactory function. $J$ Comp Physiol A Neuroethol Sens Neural Behav Physiol 185: 297-304, 1999.

HUDSON R, LASKA M, PLOOG D: A new method for testing perceptual and learning capacities in unrestrained small primates. Folia Primatol 59: 56-60, 1992.

HUMMEL T, GOLLISCH R, WILDT G, KOBAL G: Changes in olfactory perception during the menstrual cycle. Experientia 47: 712-715, 1991.

HUMMEL T, BENSAFI M, NIKOLAUS J, KNECHT M, LAING DG, SCHAAL B: Olfactory function in children assessed with psychophysical and electrophysiological techniques. Behav Brain Res 180: 133-138, 2007.

IRRAZABAL M, HERNANDEZ-RIVERA SP, BRIANO JG: Modeling of TNT transport from landmines: numerical approach. Chemosphere 77: 546-551, 2009.

JACOB TJ, FRASER C, WANG L, WALKER V, O'CONNOR S: Psychophysical evaluation of responses to pleasant and mal-odour stimulation in human subjects; adaptation, dose response and gender differences. Int $J$ Psychophysiol 48: 67-80, 2003.

JAEGER SR, MCRAE JF, SALZMAN Y, WILLIAMS L, NEWCOMB RD: A preliminary investigation into a genetic basis for cis-3-hexen-1-ol odour perception: a genome-wide association approach. Food Qual Prefer 21: 121-131, 2010.

JANCKE L: The plastic human brain. Restor Neurol Neurosci 27: 521-538, 2009.

JEZIERSKI T, ADAMKIEWICZ E, WALCZAK M, SOBCZYNSKA M, GORECKA-BRUZDA A, ENSMINGER J, PAPET E: Efficacy of drug detection by fully-trained police dogs varies by breed, training level, type of drug and search environment. Forensic Sci Int 237: 112-118, 2014.

JOHNSON EW: CaBPs and other immunohistochemical markers of the human vomeronasal system: a comparison with other mammals. Microsc Res Tech 41: 530-541, 1998. 
JOHNSTON JM: Canine Detection Capabilities: Operational Implication of Recent R\&D Findings. Institute of Biological Detection Systems, Auburn University, 1999.

KAISE H: Olfactory studies in the dog. Kita Kanto Igaku 19: 369-408, 1969.

KAUHANEN E, HARRI M, NEVALAINEN A, NEVALAINEN T: Validity of detection of microbial growth in buildings by trained dogs. Environ Int 28: 153-157, 2002.

KAYSER J, TENKE CE, KROPPMANN CJ, ALSCHULER DM, BEN-DAVID S, FEKRI S, BRUDER GE, KJELDMAND L, SALAZAR LT, LASKA M: Olfactory sensitivity for sperm-attractant aromatic aldehydes: a comparative study in human subjects and spider monkeys. J Comp Physiol A Neuroethol Sens Neural Behav Physiol 197: 15-23, 2011.

KLEENE SJ: The electrochemical basis of odor transduction in vertebrate olfactory cilia. Chem Senses 33: 839-859, 2008.

KRESTEL D, PASSE D, SMITH JC, JONSSON L: Behavioral determination of olfactory thresholds to amyl acetate in dogs. Neurosci Biobehav Rev 8: 169-174, 1984.

KURY J, STROBEL R: Nitromethane K-9 Detection Limit. Lawrence Livermore National Laboratory, Bureau of Alcohol, Tobacco and Firearms, 2003.

LABERGE F, HARA TJ: Electrophysiological demonstration of independent olfactory receptor types and associated neuronal responses in the trout olfactory bulb. Comp Biochem Physiol A Mol Integr Physiol 137: 397-408, 2004.

LARSSON L, LASKA M: Ultra-high olfactory sensitivity for the human sperm-attractant aromatic aldehyde bourgeonal in CD-1 mice. Neurosci Res 71: 355-360, 2011.

LARSSON M, FINKEL D, PEDERSEN NL: Odor identification: influences of age, gender, cognition, and personality. J Gerontol B Psychol Sci Soc Sci 55: P304-P310, 2000.

LASKA M: Olfactory discrimination ability for aliphatic c6 alcohols as a function of presence, position, and configuration of a double bond. Chem Senses 30: 755-760, 2005.

LASKA M, HUBENER F: Olfactory discrimination ability for homologous series of aliphatic ketones and acetic esters. Behav Brain Res 119: 193-201, 2001.

LASKA M, HUDSON R: Assessing olfactory performance in a New World primate, Saimiri sciureus. Phys Behav 53: 89-95, 1993.

LASKA M, SEIBT A: Olfactory sensitivity for aliphatic alcohols in squirrel monkeys and pigtail macaques. J Exp Biol 205: 1633-1643, 2002a.

LASKA M, SEIBT A: Olfactory sensitivity for aliphatic esters in squirrel monkeys and pigtail macaques. Behav Brain Res 134: 165-174, 2002b.

LASKA M, TEUBNER P: Odor structure-activity relationships of carboxylic acids correspond between squirrel monkeys and humans. Am J Physiol 274: R1639-R1645, 1998.

LASKA M, AYABE-KANAMURA S, HUBENER F, SAITO S: Olfactory discrimination ability for aliphatic odorants as a function of oxygen moiety. Chem Senses 25: 189-197, 2000a.

LASKA M, SEIBT A, WEBER A: 'Microsmatic' primates revisited: olfactory sensitivity in the squirrel monkey. Chem Senses 25: 47-53, 2000b.

LASKA M, HOFMANN M, SIMON Y: Olfactory sensitivity for aliphatic aldehydes in squirrel monkeys and pigtail macaques. J Comp Physiol A Neuroethol Sens Neural Behav Physiol 189: 263-271, 2003.

LASKA M, FENDT M, WIESER A, ENDRES T, HERNANDEZ SALAZAR LT, APFELBACH R: Detecting danger or just another odorant? Olfactory sensitivity for the fox odor component 2,4,5-trimethylthiazoline in four species of mammals. Physiol Behav 84: 211-215, 2005a.

LASKA M, GENZEL D, WIESER A: The number of functional olfactory receptor genes and the relative size of olfactory brain structures are poor predictors of olfactory discrimination performance with enantiomers. Chem Senses 30: 171-175, 2005b.

LASKA M, HOFELMANN D, HUBER D, SCHUMACHER M: The frequency of occurrence of acyclic monoterpene alcohols in the chemical environment does not determine olfactory sensitivity in nonhuman primates. $J$ Chem Ecol 32: 1317-1331, 2006a. 
LASKA M, RIVAS BAUTISTA RM, HERNANDEZ SALAZAR LT: Olfactory sensitivity for aliphatic alcohols and aldehydes in spider monkeys (Ateles geoffroyi). Am J Phys Anthropol 129: 112-120, $2006 \mathrm{~b}$.

LASKA M, BAUTISTA RM, HOFELMANN D, STERLEMANN V, SALAZAR LT: Olfactory sensitivity for putrefaction-associated thiols and indols in three species of non-human primate. J Exp Biol 210: 4169-4178, $2007 \mathrm{a}$.

LASKA M, JOSHI D, SHEPHERD GM: Olfactory discrimination ability of CD-1 mice for aliphatic aldehydes as a function of stimulus concentration. J Comp Physiol A Neuroethol Sens Neural Behav Physiol 193: 955-961, $2007 b$.

LASKA M, ROSANDHER A, HOMMEN S: Olfactory discrimination of aliphatic odorants at 1 ppm: too easy for CD-1 mice to show odor structure-activity relationships? J Comp Physiol A Neuroethol Sens Neural Behav Physiol 194: 971-980, 2008a.

LASKA M, SVELANDER M, AMUNDIN M: Successful acquisition of an olfactory discrimination paradigm by South African fur seals, Arctocephalus pusillus. Phys Behav 93: 1033-1038, $2008 \mathrm{~b}$.

LASKA M, PERSSON O, HERNANDEZ SALAZAR LT: Olfactory sensitivity for alkylpyrazines-a comparative study in CD-1 mice and spider monkeys. J Exp Zool A Ecol Genet Physiol 311: 278-288, 2009.

LASKA M, LORD E, SELIN S, AMUNDIN M: Olfactory discrimination of aliphatic odorants in South African fur seals (Arctocephalus pusillus). J Comp Psychol 124: 187-193, 2010.

LAWLESS HT: A simple alternative analysis of threshold data determined by ascending forced-choice methods of limits. J Sens Stud 25: 332-346, 2010.

LINSCHOTEN MR, HARVEY LO JR, ELLER PM, JAFEK BW: Fast and accurate measurement of taste and smell thresholds using a maximum-likelihood adaptive staircase procedure. Percept Psychophys 63: 1330-1347, 2001.

LORENZO N, WAN T, HARPER RJ, HSU YL, CHOW M, ROSE S, FURTON KG: Laboratory and field experiments used to identify Canis lupus var. familiaris active odor signature chemicals from drugs, explosives, and humans. Anal Bioanal Chem 376: 1212-1224, 2003.

LOTSCH J, LANGE C, HUMMEL T: A simple and reliable method for clinical assessment of odor thresholds. Chem Senses 29: 311-317, 2004.

LOTVEDT PK, MURALI SK, HERNANDEZ SALAZAR LT, LASKA M: Olfactory sensitivity for "green odors" (aliphatic $\mathrm{C}(6)$ alcohols and $\mathrm{C}(6)$ aldehydes) - a comparative study in male CD-1 mice (Mus musculus) and female spider monkeys (Ateles geoffroyi). Pharmacol Biochem Behav 101: 450-457, 2012.

LUNDSTROM JN, HUMMEL T, OLSSON MJ: Individual differences in sensitivity to the odor of 4,16-androstadien3-one. Chem Senses 28: 643-650, 2003.

LUNDSTROM JN, MCCLINTOCK MK, OLSSON MJ: Effects of reproductive state on olfactory sensitivity suggest odor specificity. Biol Psychol 71: 244-247, 2006.

MACMILLAN NA, CREELMAN DC: Detection Theory: A User's Guide. Cambridge University Press, Cambridge, 1991.

MAHONEY A, WEETJENS BJ, COX C, BEYENE N, REITHER K, MAKINGI G, JUBITANA M, KAZWALA R, MFINANGA GS, KAHWA A, DURGIN A, POLING A: Pouched rats' detection of tuberculosis in human sputum: comparison to culturing and polymerase chain reaction. Tuberc Res Treat 2012: 716989, 2012.

MAINLAND JD, BREMNER EA, YOUNG N, JOHNSON BN, KHAN RM, BENSAFI M, SOBEL N: Olfactory plasticity: one nostril knows what the other learns. Nature 419: 802, 2002.

MALNIC B, HIRONO J, SATO T, BUCK LB: Combinatorial receptor codes for odors. Cell 96: 713-723, 1999.

MARSHALL DA, MOULTON DG: Olfactory sensitivity to alpha-ionone in humans and dogs. Chem Senses 6: 1981.

MARTINEC NOVÁKOVÁ L, HAVLÍČEK J, ROBERTS SC: Olfactory processing and odor specificity: a meta-analysis of menstrual cycle variation in olfactory sensitivity. Anthopol Rev 77: 331-345, 2014.

MCCULLOCH M, JEZIERSKI T, BROFFMAN M, HUBBARD A, TURNER K, JANECKI T: Diagnostic accuracy of canine scent detection in early- and late-stage lung and breast cancers. Integr Cancer Ther 5: 30-39, 2006.

MCCULLOCH M, TURNER K, BROFFMAN M: Lung cancer detection by canine scent: will there be a lab in the lab? Eur Respir J 39: 511-512, 2012. 
MGODE GF, WEETJENS BJ, NAWRATH T, LAZAR D, COX C, JUBITANA M, MAHONEY A, KUIPERS D, MACHANG'U RS, WEINER J, SCHULZ S, KAUFMANN SH: Mycobacterium tuberculosis volatiles for diagnosis of tuberculosis by Cricetomys rats. Tuberculosis (Edinb) 92: 535-542, 2012.

MOBERG PJ, AGRIN R, GUR RE, GUR RC, TURETSKY BI, DOTY RL: Olfactory dysfunction in schizophrenia: a qualitative and quantitative review. Neuropsychopharmacology 21: 325-340, 1999.

MOHEDANO-MORIANO A, PRO-SISTIAGA P, UBEDA-BAÑON I, DE LA ROSA-PRIETO C, SAIZ-SANCHEZ D, MARTINEZ-MARCOS A: V1R and V2R segregated vomeronasal pathways to the hypothalamus. Neuroreport 19: 1623-1626, 2008.

MOMBAERTS P: The human repertoire of odorant receptor genes and pseudogenes. Annu Rev Genomics Hum Genet 2: 493-510, 2001.

MOORE CH, PUSTOVYY O, DENNIS JC, MOORE T, MORRISON EE, VODYANOY VJ: Olfactory responses to explosives associated odorants are enhanced by zinc nanoparticles. Talanta 88: 730-733, 2012.

MORAN DT, JAFEK BW, ROWLEY JC 3RD: The vomeronasal (Jacobson's) organ in man: ultrastructure and frequency of occurrence. J Steroid Biochem Mol Biol 39: 545-552, 1991.

MORI K, SHEPHERD GM: Emerging principles of molecular signal processing by mitral/tufted cells in the olfactory bulb. Semin Cell Biol 5: 65-74, 1994.

MOULTON DG, ASHTON EH, EAYRS JT: Studies in olfactory acuity. 4. Relative detectability of $n$-aliphatic acids by the dog. Anim Behav 8: 117-128, 1960.

MURAMOTO K, HAGINO-YAMAGISHI K, TONOSAKI K, KABA H: Accessory olfactory bulb neurons are required for maintenance but not induction of V2R vomeronasal receptor gene expression in vitro. Neurosci Lett 500: 6-9, 2011.

NAVARRETE-PALACIOS E, HUDSON R, REYES-GUERRERO G, GUEVARA-GUZMAN R: Lower olfactory threshold during the ovulatory phase of the menstrual cycle. Biol Psychol 63: 269-279, 2003.

NEUHAUS W: Uber die Riechscharfe des Hundes fur Fettsauren. Z Vergl Physiol 35: 527-552, 1953.

NEVITT GA: Olfactory foraging by Antarctic procellariiform seabirds: life at high Reynolds numbers. Biol Bull 198: 245-253, 2000.

NICOLLINI P: Olfactory stimulation and its recession (in Italian). Arch Ital Sci Farmacol 4: 109-172, 1954.

OKA Y, TAKAI Y, TOUHARA K: Nasal airflow rate affects the sensitivity and pattern of glomerular odorant responses in the mouse olfactory bulb. J Neurosci 29: 12070-12078, 2009.

OLSSON P, LASKA M: Human male superiority in olfactory sensitivity to the sperm attractant odorant bourgeonal. Chem Senses 35: 427-432, 2010.

PARTYKA ML, BOND RF, FARRAR J, FALCO A, CASSENS B, CRUSE A, ATWILL ER: Quantifying the sensitivity of scent detection dogs to identify fecal contamination on raw produce. $J$ Food Prot 77: 6-14, 2014.

PAUSE BM: Processing of body odor signals by the human brain. Chemosens Percept 5: 55-63, 2012.

PAUSE BM, MIRANDA A, GODER R, ALDENHOFF JB, FERSTL R: Reduced olfactory performance in patients with major depression. $J$ Psychiatr Res 35: 271-277, 2001.

PAUSE BM, KRAUEL K, SCHRADER C, SOJKA B, WESTPHAL E, MULLER-RUCHHOLTZ W, FERSTL R: The human brain is a detector of chemosensorily transmitted HLA-class I-similarity in same- and opposite-sex relations. Proc Biol Sci 273: 471-478, 2006.

PICKEL D, MANUCY GP, WALKER DB, HALL SB, WALKER JC: Evidence for canine olfactory detection of melanoma. Appl Anim Behav Sci 89: 107-116, 2004.

POLING A, WEETJENS B, COX C, BEYENE NW, BACH H, SULLY A: Using trained pouched rats to detect land mines: another victory for operant conditioning. J Appl Behav Anal 44: 351-355, 2011.

QUIGNON P, GIRAUD M, RIMBAULT M, LAVIGNE P, TACHER S, MORIN E, RETOUT E, VALIN AS, LINDBLAD-TOH K, NICOLAS J, GALIBERT F: The dog and rat olfactory receptor repertoires. Genome Biol 6: R83, 2005.

RABIN MD, CAIN WS: Determinants of measured olfactory sensitivity. Percept Psychophys 39: 281-286, 1986.

SAVIC I, LINDSTROM P: PET and MRI show differences in cerebral asymmetry and functional connectivity between homo- and heterosexual subjects. Proc Natl Acad Sci U S A 105: 9403-9408, 2008. 
SAVIC I, BERGLUND H, GULYAS B, ROLAND P: Smelling of odorous sex hormone-like compounds causes sex-differentiated hypothalamic activations in humans. Neuron 31: 661-668, 2001.

SAXTON TK, LYNDON A, LITTLE AC, ROBERTS SC: Evidence that androstadienone, a putative human chemosignal, modulates women's attributions of men's attractiveness. Horm Behav 54: 597-601, 2008.

SEUBERT J, FREIHERR J, FRASNELLI J, HUMMEL T, LUNDSTROM JN: Orbitofrontal cortex and olfactory bulb volume predict distinct aspects of olfactory performance in healthy subjects. Cereb Cortex 23: 2448-2456, 2013.

SHEPHERD GM: The human sense of smell: are we better than we think? PLoS Biol 2: E146, 2004.

SINGH S: Sensors - an effective approach for the detection of explosives. J Hazard Mater 144: 15-28, 2007.

SMITH TD, BHATNAGAR KP, TULADHAR P, BURROWS AM: Distribution of olfactory epithelium in the primate nasal cavity: are microsmia and macrosmia valid morphological concepts? Anat Rec A Discov Mol Cell Evol Biol 281: 1173-1181, 2004.

SMITH TD, LAITMAN JT, BHATNAGAR KP: The shrinking anthropoid nose, the human vomeronasal organ, and the language of anatomical reduction. Anat Rec (Hoboken) 297: 2196-2204, 2014.

SOBEL N, KHAN RM, HARTLEY CA, SULLIVAN EV, GABRIELI JDE: Sniffing longer rather than stronger to maintain olfactory detection threshold. Chem Senses 25: 1-8, 2000.

SONDERGAARD LV, HOLM IE, HERSKIN MS, DAGNAES-HANSEN F, JOHANSEN MG, JORGENSEN AL, LADEWIG J: Determination of odor detection threshold in the Gottingen minipig. Chem Senses 35: 727-734, 2010.

SONODA H, KOHNOE S, YAMAZATO T, SATOH Y, MORIZONO G, SHIKATA K, MORITA M, WATANABE A, MORITA M, KAKEJI Y, INOUE F, MAEHARA Y: Colorectal cancer screening with odour material by canine scent detection. Gut 60: 814-819, 2011.

STENSAAS LJ, LAVKER RM, MONTI-BLOCH L, GROSSER BI, BERLINER DL: Ultrastructure of the human vomeronasal organ. J Steroid Biochem Mol Biol 39: 553-560, 1991.

STEVENS JC, DADARWALA AD: Variability of olfactory threshold and its role in assessment of aging. Percept Psychophys 54: 296-302, 1993.

STEVENS JC, CAIN WS, BURKE RJ: Variability of olfactory threshold. Chem Senses 13: 643-653, 1988.

STORAN MJ, KEY B: Septal organ of Gruneberg is part of the olfactory system. J Comp Neurol 494: 834-844, 2006.

STRONG V, BROWN S, HUYTON M, COYLE H: Effect of trained Seizure Alert Dogs on frequency of tonic-clonic seizures. Seizure 11: 402-405, 2002.

SVARTBERG K, FORKMAN B: Personality traits in the domestic dog (Canis familiaris). Appl Anim Behav Sci 79: 133-155, 2002.

TACHER S, QUIGNON P, RIMBAULT M, DREANO S, ANDRE C, GALIBERT F: Olfactory receptor sequence polymorphism within and between breeds of dogs. J Hered 96: 812-816, 2005.

THANOS PK, ROBISON LS, ROBINSON JK, MICHAELIDES M, WANG GJ, VOLKOW ND: Obese rats with deficient leptin signaling exhibit heightened sensitivity to olfactory food cues. Synapse 67: 171-178, 2013.

TOLEDANO A, BORROMEO S, LUNA G, MOLINA E, SOLANA AB, GARCIA-POLO P, HERNANDEZ JA, ALVAREZ-LINERA J: Objective assessment of olfactory function using functional magnetic resonance imaging. Acta Otorrinolaringol Esp 63: 280-285, 2012.

TROTIER D: Vomeronasal organ and human pheromones. Eur Ann Otorhinolaryngol Head Neck Dis 128: 184-190, 2011.

TROTIER D, DOVING KB: Functional role of receptor neurons in encoding olfactory information. J Neurobiol 30: 58-66, 1996.

TROTIER D, ELOIT C, WASSEF M, TALMAIN G, BENSIMON JL, DOVING KB, FERRAND J: The vomeronasal cavity in adult humans. Chem Senses 25: 369-380, 2000.

TURIN L: A method for the calculation of odor character from molecular structure. $J$ Theor Biol 216: 367-385, 2002.

TURIN L, YOSHII F: Structure/odor relations: a modern perspective. In: Handbook of Olfaction and Gustation. Marcel Dekker, New York, 2003, pp 275-294.

VOSSHALL LB: Laying a contovrsial smell theory to rest. Proc Natl Acad Sci U S A 112: 6525-6526, 2015. 
WALKER DB, WALKER JC, CAVNAR PJ, TAYLOR JL, PICKEL DH, HALL SB, SUAREZ JC: Naturalistic quantification of canine olfactory sensitivity. Appl Anim Behav Sci 97: 241-254, 2006.

WALKER JC, JENNINGS RA: Comparison of odor perception in humans and animanls. In: Human Sense of Smell. LAING DG, DOTY RL, BREIPOHL W (eds), Springer Verlag, Berlin Heidelberg, 1991, pp 261-280.

WALKER JC, HALL SB, WALKER DB, KENDAL-REED MS, HOOD AF, NIU XF: Human odor detectability: new methodology used to determine threshold and variation. Chem Senses 28: 817-826, 2003.

WALLEN H, ENGSTROM I, HERNANDEZ SALAZAR LT, LASKA M: Olfactory sensitivity for six amino acids: a comparative study in CD-1 mice and spider monkeys. Amino Acids 42: 1475-1485, 2012.

WANG HW, WYSOCKI CJ, GOLD GH: Induction of olfactory receptor sensitivity in mice. Science 260: 998-1000, 1993.

WANG L, CHEN L, JACOB T: Evidence for peripheral plasticity in human odour response. $J$ Physiol 554: 236-244, 2004.

WELGE-LUSSEN A, WATTENDORF E, SCHWERDTFEGER U, FUHR P, BILECEN D, HUMMEL T, WESTERMANN B: Olfactory-induced brain activity in Parkinson's disease relates to the expression of eventrelated potentials: A functional magnetic resonance imaging study. Neuroscience 162: 537-543, 2009.

WELCH JB: A detector dog for screwworms (Diptera: Calliphoridae). J Econ Entomol 83: 1932-1934, 1990.

WELLS DL, HEPPER PG: Directional tracking in the domestic dog, Canis familiaris. Appl Anim Behav Sci 84: 297-305, 2003.

WILLIS CM, CHURCH SM, GUEST CM, COOK WA, MCCARTHY N, BRANSBURY AJ, CHURCH MR, CHURCH JC: Olfactory detection of human bladder cancer by dogs: proof of principle study. BMJ 329: 712, 2004.

WILSON DA: Comparison of odor receptive field plasticity in the rat olfactory bulb and anterior piriform cortex. J Neurophysiol 84: 3036-3042, 2000.

WILSON DA, STEVENSON RJ: The fundamental role of memory in olfactory perception. Trends Neurosci 26: 243-247, 2003.

WILSON DA, STEVENSON RJ: Learning to Smell. The Johns Hopkins University Press, Baltimore, Maryland, 2006.

WILSON RI, MAINEN ZF: Early events in olfactory processing. Annu Rev Neurosci 29: 163-201, 2006.

WILTROUT C, DOGRA S, LINSTER C: Configurational and non configurational interactions between odorants in binary mixtures. Behav Neurosci 117: 236-245, 2003.

WISE PM, BIEN N, WYSOCKI CJ: Two rapid odor threshold methods compared to a modified method of constant stimuli. Chemosens Percept 1: 16-23, 2008.

WRIGHT RH: Odor and molecular vibration: neural coding of olfactory information. $J$ Theor Biol 64: 473-502, 1977.

WU XL, YU CS, FAN FM, ZHANG KY, ZHU CZ, WU T, LI KC, CHAN P: Correlation between progressive changes in piriform cortex and olfactory performance in early Parkinson's disease. Eur Neurol 66: 98-105, 2011.

WYSOCKI CJ, GILBERT AN: National geographic smell survey. Effects of age are heterogenous. Ann N Y Acad Sci 561: $12-28,1989$.

WYSOCKI CJ, DALTON P, BRODY MJ, LAWLEY HJ: Acetone odor and irritation thresholds obtained from acetone-exposed factory workers and from control (occupationally unexposed) subjects. Am Ind Hyg Assoc J 58: 704-712, 1997.

YEE KK, WYSOCKI CJ: Odorant exposure increases olfactory sensitivity: olfactory epithelium is implicated. Physiol Behav 72: 705-711, 2001.

YOUNG JM, MASSA HF, HSU L, TRASK BJ: Extreme variability among mammalian V1R gene families. Genome Res 20: 10-18, 2010.

ZARZO M: The sense of smell: molecular basis of odorant recognition. Biol Rev Camb Philos Soc 82: 455-479, 2007.

ZHANG W, ZHU G, TAN L, YANG J, CHEN Y, LIU Q, SHEN Q, CHEN J, ZHANG L: Role of olfaction in the foraging behavior and trial-and-error learning in short-nosed fruit bat, Cynopterus sphinx. Behav Processes 103: 23-27, 2013. 